\title{
Assessing freshwater life-stage vulnerability of an endangered Chinook salmon population to climate change influences on stream habitat
}

\author{
Jon M. Honea ${ }^{1,4, *}$, Michelle M. McClure ${ }^{2}$, Jeffrey C. Jorgensen ${ }^{1,5}$, \\ Mark D. Scheuerell ${ }^{3}$ \\ ${ }^{1}$ Conservation Biology Division, Northwest Fisheries Science Center, National Marine Fisheries Service, \\ National Oceanic and Atmospheric Administration, 2725 Montlake Blvd E., Seattle, WA 98112, USA \\ ${ }^{2}$ Fishery Resource Analysis and Monitoring Division, Northwest Fisheries Science Center, \\ National Marine Fisheries Service, National Oceanic and Atmospheric Administration, 2725 Montlake Blvd E., Seattle, \\ WA 98112, USA \\ ${ }^{3}$ Fish Ecology Division, Northwest Fisheries Science Center, National Marine Fisheries Service, \\ National Oceanic and Atmospheric Administration, 2725 Montlake Blvd E., Seattle, WA 98112, USA \\ ${ }^{4}$ Present address: Emerson College, 120 Boylston Street, Boston, MA 02116, USA \\ ${ }^{5}$ Present address: Ocean Associates, under contract to Northwest Fisheries Science Center, \\ National Oceanic and Atmospheric Administration, 2725 Montlake Blvd E., Seattle, WA 98112, USA
}

\begin{abstract}
We linked a set of climate, hydrology, landscape, and fish population models to estimate the relative influence of freshwater habitat variables on the abundance of a population of endangered stream-type Chinook salmon Oncorhynchus tshawytscha responding to a warming climate. The hydrology models estimated that increases in annual air temperature and winter precipitation would lead to increases in water temperature and changes in discharge, including higher flows during the egg-incubation period and lower flows during the summer rearing period. The spatially explicit population model estimated a resulting decline of 0 to $7 \%$ in the number of spawners, with 3 of 4 global climate models estimating a decline of 4 to $7 \%$. Increased water temperature during the summer spawning period was the most limiting among habitat variables modeled, but our modeling suggested that aggressive habitat restoration (increasing forested area and reducing impervious area) could mitigate some spawner abundance reductions. Better knowledge of the links between climate changes and habitat response, including increased streambed scour due to the larger and more frequent winter high-discharge events predicted by our hydrology models, would improve our ability to estimate climate effects on populations. Future limitation by elevated summer water temperature, and potentially egg-pocket scour, would further stress an endangered population currently limited by the percentage of fine sediment around egg pockets. Identifying such changes demonstrates the utility of models that consider climate and integrate life-stage-specific habitat influences over a species' life cycle, thereby indicating restoration actions with the potential to benefit sensitive life stages.
\end{abstract}

KEY WORDS: Life-cycle model $\cdot$ Landscape model $\cdot$ Hydrology model $\cdot$ Downscale

\section{INTRODUCTION}

To effectively manage the recovery of imperiled species, there is an imperative need for understanding the cumulative effects of climate change on habi-

\footnotetext{
${ }^{*}$ Corresponding author: jon_honea@emerson.edu
}

tat and how species respond (Groves et al. 2012, Seney et al. 2013). Each stage of a species' life history may be affected differently by changes in its habitat. For example, Radchuk et al. (2013) found positive effects from warming temperatures in all stages of an

(C) The authors 2016. Open Access under Creative Commons by Attribution Licence. Use, distribution and reproduction are unrestricted. Authors and original publication must be credited. 
endangered butterfly species except survival in its overwinter larval stage, which resulted in reduced population viability and increased extinction risk. Identifying such potential bottlenecks to recovery as a consequence of forecasted climate change, by itself and in combination with other factors, is becoming an increasingly important aspect of natural resource management (Finch et al. 2014, Runge et al. 2014).

Climate change presents a challenge to Pacific salmonids because they are philopatric and have a relatively low straying rate (Neville et al. 2006, Quinn et al. 2006, Keefer \& Caudill 2014). This pattern promotes local adaptation (Quinn \& Dittman 1990) and may limit salmonid resili-

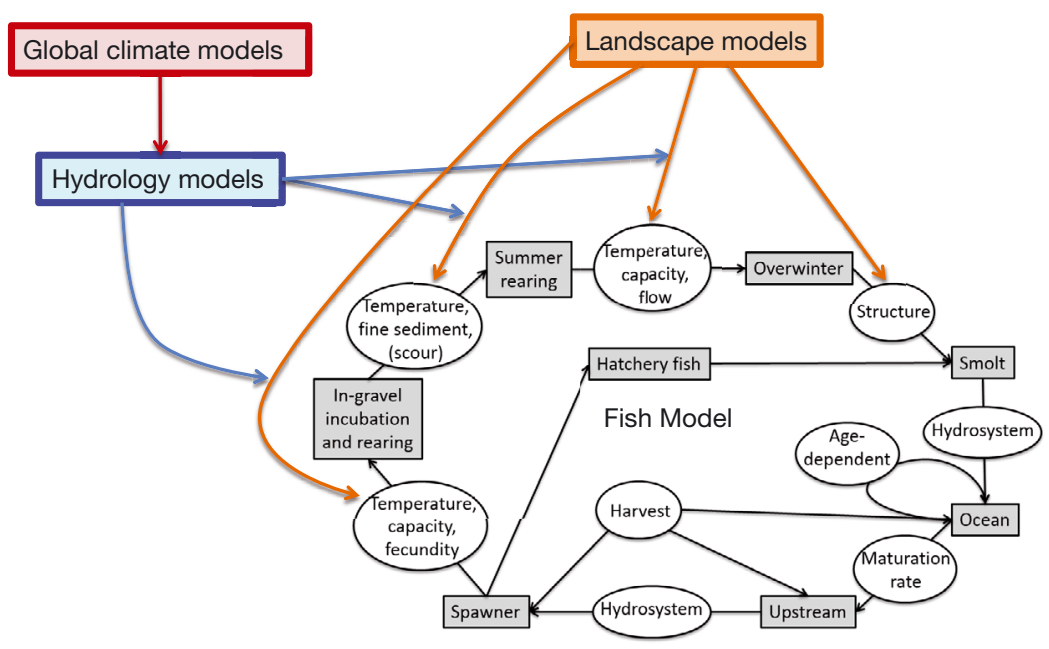

Fig. 1. Diagram of links between climate, hydrology, and landscape influences on a spring-run Chinook salmon population dynamics life-cycle model, showing where factors (ovals) influencing transitions between stages of the fish life cycle (shaded rectangles) are determined by outputs of the hydrology and landscape models. Each color represents a different model ence if changes in water temperature and discharge regimes outpace their capacity to adapt. Currently, maximum water temperatures during the summer in many western USA salmonbearing streams approach and occasionally exceed thermal preferences or tolerances of salmonids (Torgersen et al. 1999, Richter \& Kolmes 2005, Goniea et al. 2006). Future increases in air temperature and changes in mountain snowpack are projected to exacerbate high water temperatures and low flows during the summer (Mote \& Salathé 2010) as well as increase the frequency of high discharge events in other seasons (Warner et al. 2014), putting additional environmental stresses on fishes (Mantua et al. 2010). An understanding of these effects can ensure that habitat restoration efforts are targeted to ameliorate the anticipated negative impacts (Beechie et al. 2013, McClure et al. 2013). However, only a few population studies have analyzed life-stage-specific responses to climate change in a life-cycle context (e.g. Battin et al. 2007, Crozier et al. 2008, Radchuk et al. 2013). Important life-stage bottlenecks could be overlooked if the population-level influences of individual life-stage responses to climate change are not assessed (Dupont et al. 2010, Radchuk et al. 2013).

To better understand the potential vulnerability of an endangered salmon population, we linked a set of global climate models (GCMs) to a set of hydrology models to estimate changes in water temperature and discharge at key periods in the freshwater life stages of stream-type Chinook salmon Oncorhynchus tshawytscha from the Wenatchee River. We estimated the population response with a spatially ex- plicit life-cycle population model (Scheuerell et al. 2006, Honea et al. 2009), using the output (water temperature and flows) from the hydrology models as input, to ascertain which life stages are most influenced by the effects of climate change (Fig. 1). We focused on freshwater life stages because of our capacity to influence habitat changes there with restoration activities (Palmer et al. 2008, Bryant 2009, Yvon-Durocher et al. 2011). We examined climate effects on population dynamics for 2 habitat states as contrasting boundary conditions: a status quo (current) habitat and an approximation of historical habitat conditions (Jorgensen et al. 2009). We conducted a sensitivity analysis to determine which freshwater life stages were most vulnerable to climate change effects under each habitat condition and to assess the relative potential of different restoration actions for mitigating climate impacts.

\section{MATERIALS AND METHODS}

\subsection{Population}

Wenatchee River spring-run Chinook salmon Oncorhynchus tshawytscha, 1 of 3 populations that compose the endangered Upper Columbia spring-run Chinook salmon Evolutionarily Significant Unit (NMFS 1999), typically spend nearly 2 yr in freshwater after they hatch, migrate to the ocean in their second year, and return from the ocean as 4 and $5 \mathrm{yr}$ old adult spawners to the river where they hatched. 


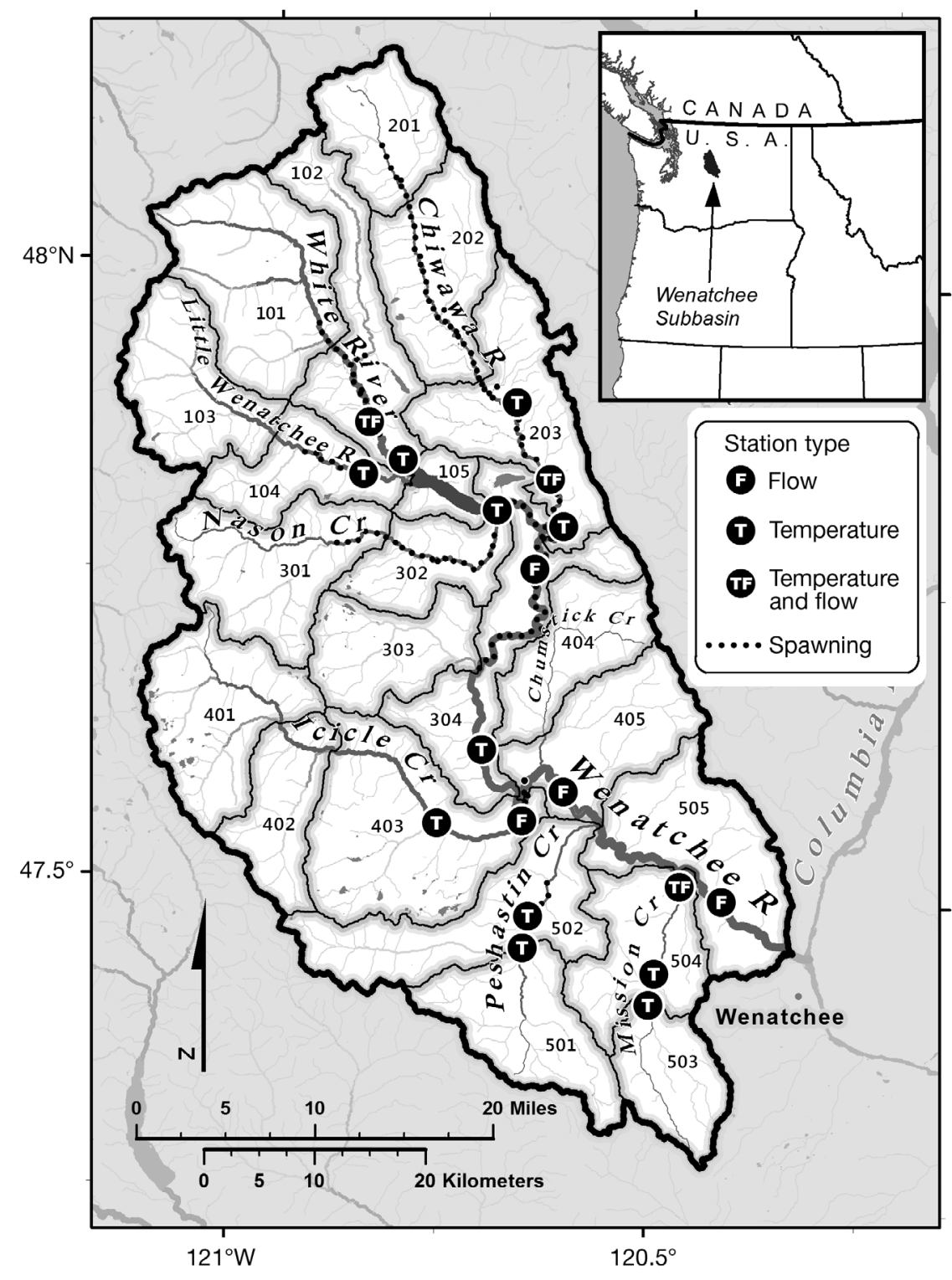

Fig. 2. The study area, showing the subbasins modeled (labeled by the final 3 digits of the sixth-field hydrologic unit code) and the temperature and stream discharge stations used for calibrating the hydrology models

the upper reaches of the mainstem Wenatchee River. The Chiwawa River and Nason Creek both have fish supplementation programs producing salmon from local broodstock intended to augment the wild population. The Icicle River supports few wild Chinook salmon but is the location of a major Chinook salmon hatchery supporting commercial and recreational harvest using broodstock from fish that originated outside of the Wenatchee River Basin population.

\subsection{Climate, hydrology, landscape, and population models linking climate to habitat condition and population response}

We used outputs from 4 GCMs to simulate future climate scenarios. To estimate changes in stream temperature and discharge in response to potential future climate, we used air temperature and precipitation estimates from the GCMs - downscaled to $150 \mathrm{~m}, 3 \mathrm{~h}$ values - as inputs to a set of local hydrology models. The output of the hydrology models, water temperature and discharge, was used as input to a population model to project population response to predicted changes in climate. More details of the climate and hydrology models can be found in the Supplement at www.int-res.com/articles/ suppl/c071p127_supp.pdf.

To assess the influence of climate change on salmon survival, we used

The Wenatchee River Basin drains about $3400 \mathrm{~km}^{2}$ of the eastern slopes of the Cascade Mountains and empties into the Columbia River, the largest North American river flowing into the Pacific Ocean (Fig. 2). Wenatchee River Basin hydrology is dominated by snowmelt with the highest flows occurring between May and July and the lowest in August and September. See Jorgensen et al. (2009) for a more detailed description of the basin. We modeled all of the major salmon-producing tributaries of the Wenatchee River, including the Chiwawa, White, and Little Wenatchee rivers, as well as Nason Creek and a spatially explicit population model calibrated for the study area (Honea et al. 2009), using changes in mean adult spawner abundance as the population response measure. Survival through 3 freshwater stages (spawning, in-gravel egg incubation and rearing, and summer rearing) was driven by functional relationships that included water temperature (Fig. 3). Another freshwater life stage, the overwinter stage, was indirectly influenced by climate because lower discharge at the end of summer increased the number of fish moving downstream into new areas for their overwintering stage. The 3 remaining life 
a) Incubation

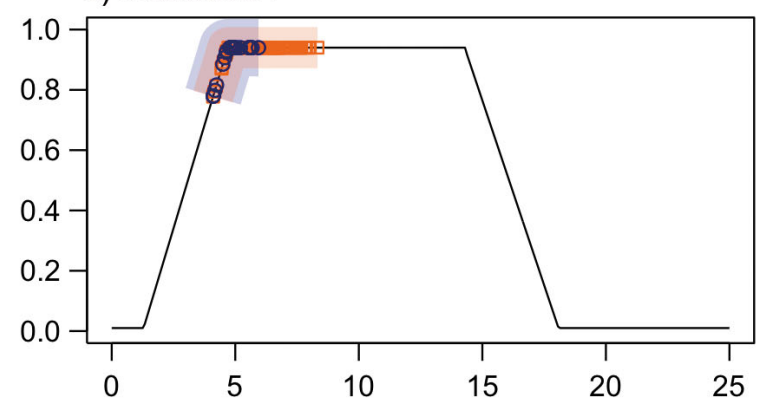

b) Summer rearing

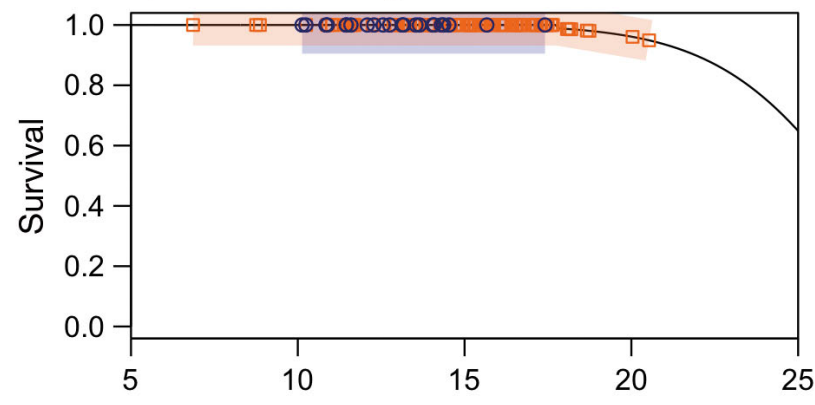

c) Spawner

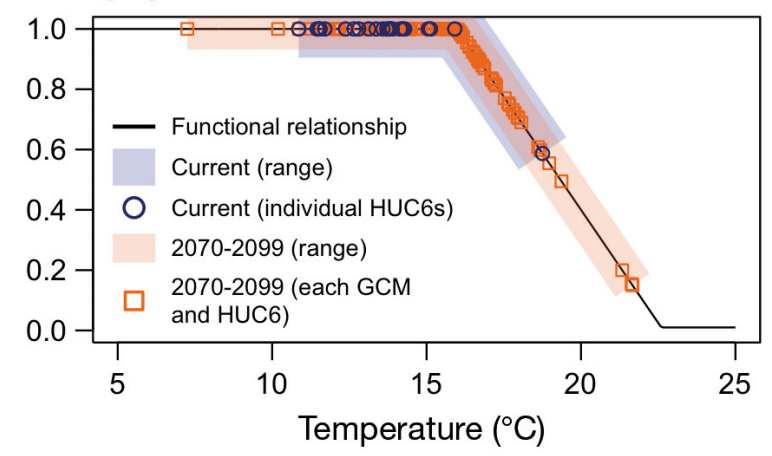

Fig. 3. Functional relationships incorporated in the population model that related water temperature to survival for several of the life stages, both at estimated current conditions and in the 2080s from outputs from hydrology modeling. These relationships included (a) in-gravel incubation and rearing survival (based on data from Velsen 1987 and Beacham \& Murray 1989); (b) summer rearing (based on data from Brett 1952, McCormick et al. 1972, and Coutant 1973); and (c) spawner survival (based on data from Cramer 2001). Symbols represent estimates for each HUC6 subbasin that have spawning and rearing fish (Fig. 2)

stages included in the population model-juvenile outmigrants (smolts), adults in the ocean, and upstream migrating adults - occur in the mainstem Columbia or in the ocean. Although climate change will likely affect those areas as well, there is insufficient information about the projected changes in those environments and their effects on salmon. Thus, our focus was on freshwater spawning and rearing habitat where there is more information about climate change-induced changes (Fig. 1). While we use spawner abundance as the response variable, the purpose of the model is not to predict actual spawner numbers in future climate conditions. Rather, we are comparing the relative influence of different habitat variables for which data are available, to assess which of these variables known to affect survival through different life stages is likely to have the greatest influence on future spawner abundance. Additional details of the population model are described in the Supplement (www.int-res.com/ articles/suppl/m071p127_supp.pdf).

We also considered the potential for more frequent high flows during the in-gravel egg incubation and rearing stage, due to increases in precipitation (Warner et al. 2014) and more transient hydrology dominated by both rain and snow (Mantua et al. 2010), to increase streambed scour and so also egg and larval fish mortality (Lapointe et al. 2000, Goode et al. 2013). To simulate the population response to greater scour due to higher flows during the ingravel stage, we included a scenario with a $25 \%$ increase in mortality through this stage. We did not include a functional relationship directly linking streambed scour to survival through this stage in the population model because of limited data on the relationship between flow and scour for this basin.

We estimated terrestrial habitat variables that affect fish survival through changes to in-stream habitats at the sixth-field hydrologic unit code (HUC6 hereafter; Seaber et al. 1987) subbasin unit scale using a set of landscape models developed for this basin that quantitatively link landscape attributes to fish habitat characteristics (Jorgensen et al. 2009). Landscape attributes included total forest cover, riparian forest cover, road density, stream channel slope, elevation, precipitation, and drainage area. See Jorgensen et al. (2009) for additional details of the landscape models. For this analysis, we expanded on our previous work in Jorgensen et al. (2009) by re-examining the landscape models to determine the key landscape variables that could be targets for action to ameliorate climate impacts on stream habitat. We did this by assessing which landscape variables were most frequently present in the highest-ranked models predicting climate-linked stream habitat variables-i.e. water temperature during spawning, in-gravel egg incubation and rearing, and summer rearing life stages.

Therefore, in this study, we modeled a total of 17 different combinations of habitat conditions coupled with climate scenarios. These combinations consisted of 2 extreme landscape states, climate estimated by 4 
Table 1. Scenarios modeled. 'Climate' refers to the drivers of the water temperature and flow data used in the population model (for details on the hydrology and global climate models, see the Supplement). 'Habitat' refers to the landscape state influencing stream habitat condition. 'Scour' refers to mortality during the in-gravel egg incubation and rearing stage

\begin{tabular}{|lccc|}
\hline Scenario name & Climate & Habitat & Scour \\
\hline CurrentClimate-CurrentHabitat-CurrentScour & Current & Current & Current \\
Warmest-CurrentHabitat-CurrentScour & ECHAM5 & Current & Current \\
Warmer1-CurrentHabitat-CurrentScour & CCSM3 & Current & Current \\
Warmer2-CurrentHabitat-CurrentScour & CGCM3.1 & Current & Current \\
Warm-CurrentHabitat-CurrentScour & PCM1 & Current & Current \\
Warmest-HistoricalHabitat-CurrentScour & ECHAM5 & Historical & Current \\
Warm1-HistoricalHabitat-CurrentScour & CCSM3 & Historical & Current \\
Warm2-HistoricalHabitat-CurrentScour & CGCM3.1 & Historical & Current \\
Warm-HistoricalHabitat-CurrentScour & PCM1 & Current & Current \\
Warmest-CurrentHabitat-IncreasedScour & ECHAM5 & Current & $+25 \%$ \\
Warm1-CurrentHabitat-IncreasedScour & CCSM3 & Current & $+25 \%$ \\
Warm2-CurrentHabitat-IncreasedScour & CGCM3.1 & Current & $+25 \%$ \\
Warm-CurrentHabitat-IncreasedScour & PCM1 & Historical & $+25 \%$ \\
Warmest-HistoricalHabitat-IncreasedScour & ECHAM5 & Historical & $+25 \%$ \\
Warm1-HistoricalHabitat-IncreasedScour & CCSM3 & Historical & $+25 \%$ \\
Warm2-HistoricalHabitat-IncreasedScour & CGCM3.1 & Historical & $+25 \%$ \\
Warm-HistoricalHabitat-IncreasedScour & PCM1 & & $+25 \%$ \\
\hline
\end{tabular}

CGMs, and an additional factor to test the hypothesis that increased scour mortality may play a significant role in determining spawner abundance (Table 1). We modeled the 2 landscape states as contrasting boundary conditions: current and historical condition. The current condition included estimates from the landscape models of the current values of habitat variables in each HUC6 subbasin. Historical conditions for the study area were estimated with the landscape models by reverting the landscape variables influenced by human development to their expected historical values. For example, forest clearcuts were reverted to fully vegetated states and roads, and other anthropogenic impervious surfaces were converted to ecoregionally appropriate land-cover classes (Jorgensen et al. 2009). For each of the 2 landscape states, current and historical, we altered the resulting habitat variables associated with climate (i.e. water temperature and flow) by the change from current to future estimated by the hydrology models starting with air temperature and precipitation output from each of the 4 GCMs. Finally, to each of these 8 scenarios ( 2 landscape states $\times 4$ GCMs), we added an additional variable: a $25 \%$ increase in mortality during the in-gravel egg incubation and rearing stage.

\subsection{Life-stage vulnerability analysis}

We conducted a sensitivity analysis to determine which predicted change in the habitat variables had the greatest influence on population dynamics due to their impacts at particular life-history stages, as well as to estimate which landscape variables were most strongly associated with the influential habitat variables. We did so by running the population model, altering only one of the climate-driven habitat variables at a time while holding all other variables constant at their estimated current values and comparing the change in spawner abundance (relative to current conditions) resulting from each model run. For water temperature during the in-gravel, summer rearing, and spawner periods and for low discharge at the end of the summer rearing period, we used the hydrology model output values for each of the GCMs. In this comparison of the relative influence of variables, we also included a model run using only $25 \%$ increased mortality during the in-gravel period to simulate the effects of increased streambed scour.

\section{RESULTS}

In response to habitat changes produced by the linked climate, hydrology, and landscape models (for climate and hydrology results, see the Supplement at www.int-res.com/articles/suppl/c071p127_supp.pdf), the population model forecasted either no change or a small decline in mean spawner abundance, depending on GCM. Three GCMs resulted in a 4 to $7 \%$ decline in spawner numbers (Warmest-CurrentHabitat-CurrentScour, Warmer1-CurrentHabitat-Current 


\section{Change in spawners (\%)}

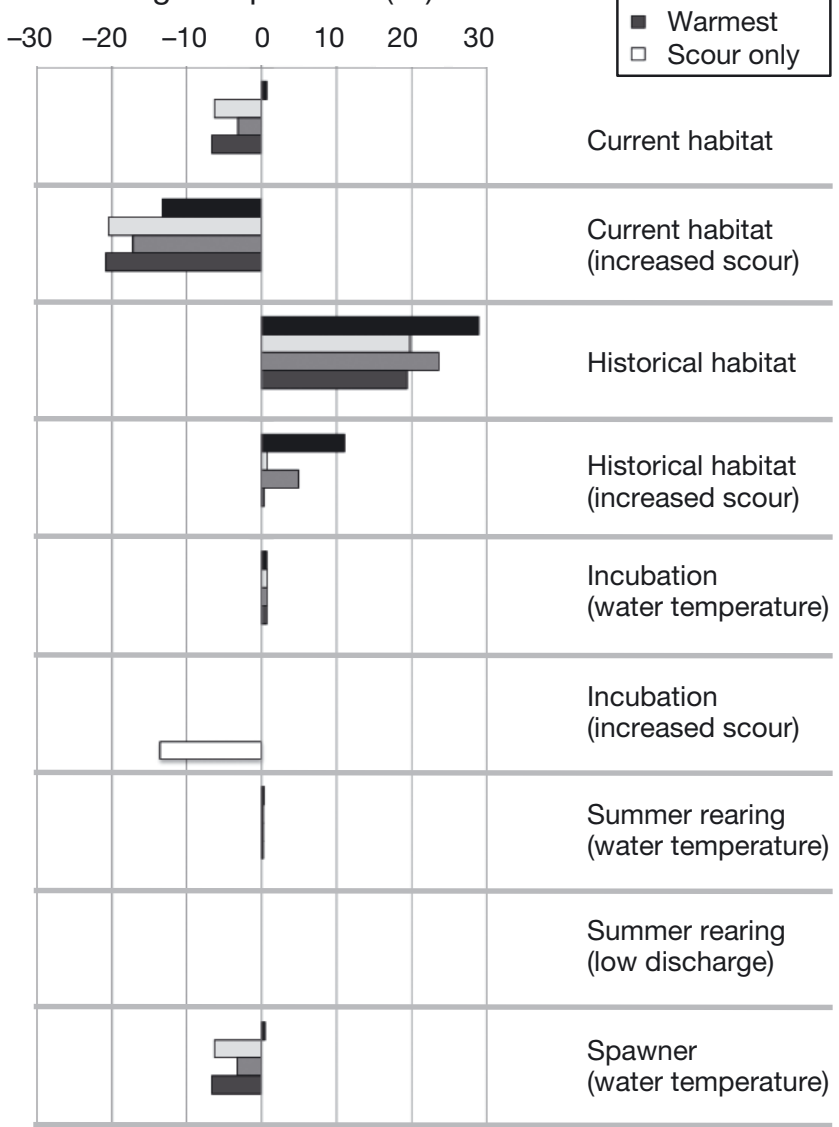

Fig. 4. Changes in wild spawner abundance (as percent change relative to estimated current numbers) resulting from scenarios of future climate under current habitat conditions, historical conditions, and to changes in individual habitat parameters in the sensitivity analysis. Increased stream-bed scour effects were simulated as a $25 \%$ increase in mortality during the in-gravel incubation and rearing period

Scour, and Warmer2-CurrentHabitat-CurrentScour in Table 1); however, Warm-CurrentHabitat-Current Scour, which included the GCM projecting the smallest changes in air temperature, resulted in little change in spawner numbers (Fig. 4). For the 3 GCM scenarios where a decline in wild spawner abundance was observed, the spatial pattern and magnitude of the change in spawner numbers was similar, with most of the decline occurring in lower Nason Creek and the upper Wenatchee River (Fig. 5), the lowest in elevation and warmest of the major spawning areas. Historical habitat conditions with end-ofcentury climate conditions estimated by all GCMs resulted in an increase in mean spawner abundance of nearly $30 \%$ versus future climate at current habi-

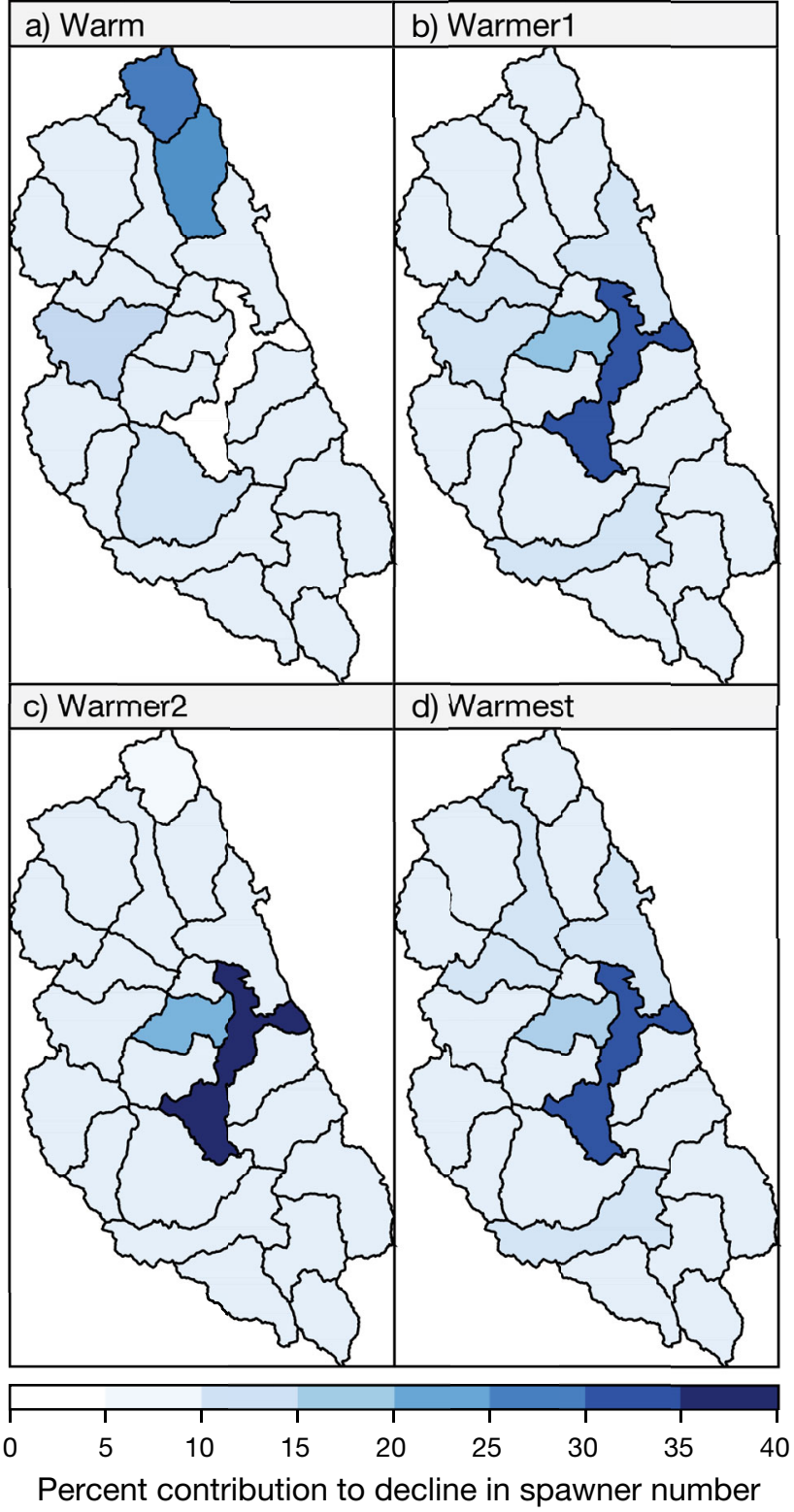

Fig. 5. Percent contribution of each HUC6 subbasin to the decline in spawner abundance, including effects of water temperature on incubation, summer rearing, and spawning stages as well as low discharge at the end of the summer rearing stage: (a) Warm (PCM1); (b) Warmer1 (CCSM3); (c)

Warmer2 (CGCM3.1); (d) Warmest (ECHAM5)

tat conditions (Fig. 4). In the modeling of landscape links to stream habitat, upland and riparian forested area and anthropogenic impervious area appeared most frequently in the highest ranked models, indicating their greater influence on stream habitat characteristics than other landscape attributes modeled. This suggests that habitat restoration may have an important role in mitigating the effects of climate change for vulnerable populations. 


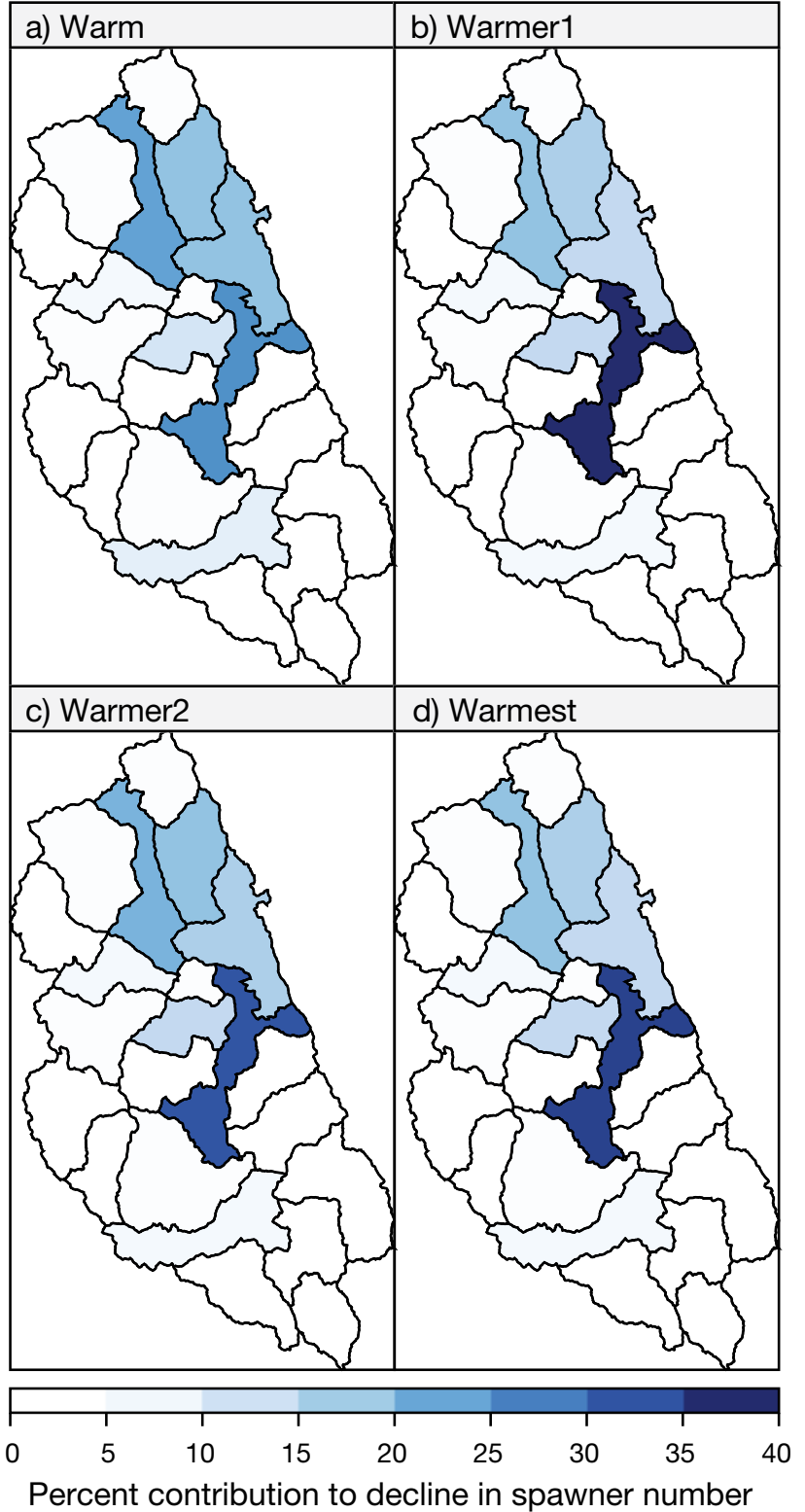

Fig. 6. Percent contribution of each HUC6 subbasin to the decline in spawner abundance, including Fig. 5 variables as well as $25 \%$ increase in mortality during the in-gravel egg incubation and rearing stage simulating response to increased streambed scour: (a) Warm (PCM1); (b) Warmer1 (CCSM3); (c) Warmer2 (CGCM3.1); (d) Warmest (ECHAM5)

Our sensitivity analysis, where we manipulated variables one at a time, revealed that the in-gravel egg and rearing life stage had the most influence on spawner abundance. When we reduced survival through the in-gravel stage by $25 \%$ to simulate the potential influence of increased streambed scour due to larger and more frequent high-discharge events during the in-gravel period, spawner abundance declined by an additional $~ 15 \%$ below numbers for the future climate and habitat scenarios (Figs. 4 \& 6). Among the life stages that had explicit habitat-survival links in our model, the one with the greatest influence on population dynamics was the spawning life stage. For all GCMs, except again Warm, end of century higher water temperature had the most substantial and negative impact on fish abundance (Fig. 4). The in-gravel and summer rearing stages responded only weakly to increased temperatures and lower summer flows, having a negligible impact on spawner abundance (Fig. 4).

\section{DISCUSSION}

Predicted increases in air temperature and changes in precipitation are likely to alter aspects of stream habitat that are important to salmon at different stages of their life history. Our linked climate and hydrology models showed increased mean and maximum water temperatures in all months and increased average and maximum discharge during the incubation period. There was variability, however, among the climate models regarding low summer discharge. Three GCMs (Warmest, Warmer1, and Warmer2 in Table 1) resulted in a lower mean and minimum discharge, while a more moderate GCM (Warm) - in terms of air temperature change - predicted a higher mean and minimum discharge relative to current conditions (see the supplement at www.int-res.com/articles/suppl/c071p127_supp.pdf) due to a projected increase in precipitation during the summer months.

When we linked these conditions to a population model, future climate caused small population declines, with the spawning life stage most affected by climate-driven changes in freshwater habitat (Fig. 4). Survival during the spawning stage was sensitive to changes in water temperature in the range predicted for the century's end (Fig. 3; Richter \& Kolmes 2005). Predicted changes in water temperature during the in-gravel and the summer rearing stages had little influence on spawner numbers (Fig. 4). The relationship between survival and water temperature during the in-gravel and summer rearing life stages was based on multiple observational experiments for each stage (see Honea et al. 2009) and is therefore likely robust. The link between survival and water temperature at the spawning life stage, in contrast, was based on only 1 data set and should be verified as more observations are made.

We found no change in spawner abundance due to the influence of reduced summer flows on juvenile 
movement downstream to overwintering habitat. The lower flows drove a greater number of juveniles to migrate downstream to reaches with more favorable flows and habitat for the overwinter period. Survival through the overwinter period was a function of the percent of cobble and boulders in downstream pool habitats, and observations indicate that availability of this type of habitat is not limiting the population (Honea et al. 2009). Therefore, when fish moved downstream as a consequence of lower flows, there was no resulting change in survival. However, more information is needed to better understand and to model survival through the overwintering stage.

With mean peak discharge during the autumn to early spring period increasing by 27 to $34 \%$ and the current $10 \mathrm{yr}$ and $100 \mathrm{yr}$ peak discharge events returning with frequencies of 4-5 yr and 9-15 yr, respectively (see the supplement), increased in-gravel egg and rearing mortality due to streambed scour is likely (Lapointe et al. 2000). Although we were unable to explicitly include in-gravel mortality from scour due to a lack of basin-specific scour estimates, spawner abundance declined by 14 to $21 \%$ below the estimates for the current climate and habitat scenario when we increased in-gravel mortality by $25 \%$ in the future climate scenarios as a sensitivity test. These estimates of scour effects are similar to estimates of Battin et al. (2007) for Chinook salmon Oncorhynchus tshawytscha in a basin where rain-onsnow events between November and February are more common than in the Wenatchee River Basin. Wenatchee River Basin hydrology is currently dominated by spring snowmelt; however, if climate estimates for the end of the century hold, it may potentially change to a more transient hydrology dominated by both rain and snow (Mantua et al. 2010), likely increasing the influence of streambed scour on in-gravel mortality.

We focused our modeling on the direct effects of climate on habitat variables with links to fish survivorship through successive life stages within freshwater habitats for salmon (Moussalli \& Hilborn 1986, Scheuerell et al. 2006, Honea et al. 2009). While this is an important first step in beginning to consider the effects of climate on the vulnerability of at-risk species, there are other steps that could be included in the future. For example, numerous studies have associated a diverse set of ocean condition indices to salmon ocean survival (e.g. Mantua et al. 1997, Scheuerell \& Williams 2005, Zabel et al. 2006); however, at this time, the net impact on conditions for salmon survival due to forecasted changes in ocean conditions and the marine food web is difficult to estimate (Bakun 1990, Snyder et al. 2003, Harley et al. 2006, Overland \& Wang 2007, Branch et al. 2013). In addition, freshwater habitat is likely to be affected by climate change indirectly - for example, via indirect effects due to climate-induced changes in demands on water for irrigation (Donley et al. 2012) or to landscape changes, such as in vegetation patterns due to changes in precipitation, air temperature, fire regime (Flannigan et al. 2000), and insect pathogens (Dalton et al. 2013). Other considerations include climate change-induced discharge and water temperature changes that may affect interactions with other organisms, such as predators (Petersen \& Kitchell 2001) or fish pathogens (Marcogliese 2001), and interactions with hatchery fish with the consequent genetic effects of interbreeding (e.g. McClure et al. 2008, Muhlfeld et al. 2014). The various potential influences not included in our study highlight the need for a better understanding of the functional forms of the relationships between habitat and survival at specific life stages and their consequences to population dynamics (Hilborn 2009).

Although we found a potential decline in Wenatchee spring Chinook salmon spawners under climate change, other regions and species may respond differently to climate change. For steelhead Oncorhynchus mykiss, some evidence suggests that decreasing summer discharge may be the most limiting factor in the Wenatchee River and elsewhere in the Upper Columbia River Basin (Wade et al. 2013). In contrast, in colder regions where cool water temperatures may be further below the high temperature tolerance threshold, warming may have the opposite effect and in some locations may lead to an increase in fish survival and production (Leppi et al. 2014).

Taking into account the influence of a changing climate on habitat will improve the likelihood that restoration actions will succeed in recovering at-risk species (Waples et al. 2009, Beechie et al. 2013). Our modeling found that the restoration actions that most addressed the impacts of increasing water temperature were restoring forests, both riparian and upland, toward estimated historical conditions and reducing anthropogenic impervious area. There is empirical and other modeling evidence that is consistent with these findings. For example, Pollock et al. (2009) found that the total amount of forest harvest within a basin was positively correlated with water temperature in 40 small basins in western Washington State. In the Wenatchee River Basin, Cristea \& Burges (2010) used a riparian shade model linked to a stream channel heat-balance model to similarly conclude that riparian restoration would mostly offset the 
effects of future warming in Nason Creek, the Icicle River, and the Wenatchee River mainstem. In another tributary of the Columbia River near the Wenatchee River Basin, Ruesch et al. (2012) used a statistical model to predict stream temperature based on flow and stream unit connectivity. They concluded that riparian restoration would partially compensate for an estimated loss of 69 to $95 \%$ of Chinook salmon habitat as a result of climate change. Elsewhere, other restoration actions may be more appropriate. For example, Battin et al. (2007) concluded that increasing habitat capacity in the lower reaches of a transitional rain and snow-melt dominated river basin by reconnecting the main channel to sidechannels and to floodplain habitat would be the most effective means of mitigating changes resulting from future climate because the lower reaches had been highly modified and disconnected from their floodplains while the higher elevation reaches were mostly already protected and pristine.

While we project that water temperature during the spawning period will be more limiting by this century's end than it currently is, and that streambed scour may become more important as well, our modeling predicts that the percentage of fine sediment in gravels during the incubation period will remain the most influential freshwater habitat variable limiting spawner abundance, as we found to be the case in our earlier study (Honea et al. 2009) for present conditions. Thus, restoration priorities for freshwater habitat could remain the same, particularly because some of the same restoration actions that impact fine sediments in incubation gravels have been shown to reduce high water temperature and high discharge extremes as well. For example, reforestation and reducing riparian grazing can promote riparian forests that shade stream channels as well as reduce runoff, leading to less erosion and reduced flashiness of discharge in response to precipitation (Beschta 1997, Medina et al. 2005). Restoring riparian forests will likely be crucial to preparing streams for the impacts of climate change (Seavy et al. 2009).

\section{CONCLUSION}

This work demonstrates the utility of examining the impacts of habitat changes on multiple life stages to identify potential bottlenecks that may drive longterm persistence. Such models may indicate a shift in the importance of different habitat variables and life stages - as with our work indicating the increasing importance of water temperature during the summer and perhaps high flows during winter and spring or reveal a vulnerable life stage amid others responding positively to change - as with the overwinter larval stage in the butterfly life-cycle model investigated by Radchuk et al. (2013). Furthermore, the apparent importance of relationships about which we have little local information, such as scour and its influence on survival during the egg incubation and in-gravel rearing period, indicates worthwhile areas for further data collection and research to guide population recovery efforts.

Acknowledgements. The downscaled dataset of GCMN estimates was provided by Pablo Carrasco of the Climate Impacts Group at the University of Washington (in collaboration with the Washington State Department of Ecology, Bonneville Power Administration, Northwest Power and Conservation Council, Oregon Water Resources Department, and the British Columbia Ministry of the Environment). Erin Rogers, then at the University of Washington Department of Civil Engineering, calibrated the DHSVMs for the Wenatchee River Basin. Both Mr. Carrasco and Ms. Rogers were guided by Alan Hamlet, then at the University of Washington Department of Civil Engineering. We also thank Lisa Crozier, Corey Phillis, and 3 anonymous reviewers for providing comments on earlier drafts; Alan Hamlet and Ray Hilborn for helpful discussions; countless field crew members who collected habitat data; and Damon Holzer for creating the map in Fig. 2. J.M.H. was supported by a postdoctoral grant from UCAR (administered through NOAA) and by Emerson College.

\section{LITERATURE CITED}

Bakun A (1990) Global climate change and intensification of coastal ocean upwelling. Science 247:198-201

Battin J, Wiley MW, Ruckelshaus MH, Palmer RN, Korb E, Bartz KK, Imaki H (2007) Projected impacts of climate change on salmon habitat restoration. Proc Natl Acad Sci USA 104:6720-6725

*Beacham TD, Murray CB (1989) Variation in developmental biology of sockeye salmon (Oncorhynchus nerka) and Chinook salmon (O. tshawytscha) in British Columbia. Can J Zool 67:2081-2089

Beechie T, Imaki H, Greene J, Wade A and others (2013) Restoring salmon habitat for a changing climate. River Res Appl 29:939-960

Beschta RL (1997) Riparian shade and stream temperature: an alternative perspective. Rangelands 19:25-28

* Branch TA, DeJoseph BM, Ray LJ, Wagner CA (2013) Impacts of ocean acidification on marine seafood. Trends Ecol Evol 28:178-186

Brett JR (1952) Temperature tolerance in young Pacific salmon, genus Oncorhynchus. J Fish Res Board Can 9: 265-309

*Bryant MD (2009) Global climate change and potential effects on Pacific salmonids in freshwater ecosystems of southeast Alaska. Clim Change 95:169-193

Coutant CC (1973) Effects of thermal shock on vulnerability of juvenile salmonids to predation. J Fish Res Board Can 30:965-973 
Cramer SP (2001) The relationship of stream habitat features to potential for production of four salmonid species. Final report to the Oregon Building Industry Association. S. P. Cramer and Associates, Gresham, OR

Cristea NC, Burges SJ (2010) An assessment of the current and future thermal regimes of three streams located in the Wenatchee River basin, Washington State: some implications for regional river basin systems. Clim Change 102:493-520

Crozier LG, Zabel RW, Hamlet AF (2008) Predicting differential effects of climate change at the population level with life-cycle models of spring Chinook salmon. Glob Change Biol 14:236-249

Dalton MM, Mote PW, Snover AK (eds) (2013) Climate change in the Northwest: implications for our landscapes, waters, and communities. Island Press, Washington, DC

* Donley EE, Naiman RJ, Marineau MD (2012) Strategic planning for instream flow restoration: a case study of potential climate change impacts in the central Columbia River basin. Glob Change Biol 18:3071-3086

D Dupont S, Dorey N, Thorndyke M (2010) What meta-analysis can tell us about vulnerability of marine biodiversity to ocean acidification? Estuar Coast Shelf Sci 89:182-185

Finch T, Pearce-Higgins JW, Leech DI, Evans KL (2014) Carry-over effects from passage regions are more important than breeding climate in determining the breeding phenology and performance of three avian migrants of conservation concern. Biodivers Conserv 23:2427-2444

Flannigan MD, Stocks BJ, Wotton BM (2000) Climate change and forest fires. Sci Total Environ 262:221-229

Goniea TM, Keefer ML, Bjornn TC, Peery CA, Bennett DH, Stuehrenberg LC (2006) Behavioral thermoregulation and slowed migration by adult fall Chinook salmon in response to high Columbia River water temperatures. Trans Am Fish Soc 135:408-419

Goode JR, Buffington JM, Tonina D, Isaak DJ and others (2013) Potential effects of climate change on streambed scour and risks to salmonid survival in snow-dominated mountain basins. Hydrol Processes 27:750-765

Groves CR, Game ET, Anderson MG, Cross M and others (2012) Incorporating climate change into systematic conservation planning. Biodivers Conserv 21:1651-1671

Harley CDG, Hughes RA, Hultgren KM, Miner BG and others (2006) The impacts of climate change in coastal marine systems. Ecol Lett 9:228-241

Hilborn R (2009) Life history models for salmon management: the challenges. In: Knudsen EE, Michael JHJ (eds) Pacific salmon environmental and life history models: advancing science for sustainable salmon in the future. American Fisheries Society, Bethesda, MD, p 23-32

Honea JM, Jorgensen JC, McClure MM, Cooney TD, Engie K, Holzer DM, Hilborn R (2009) Evaluating habitat effects on population status: influence of habitat restoration on spring-run Chinook salmon. Freshw Biol 54: 1576-1592

Jorgensen JC, Honea JM, McClure MM, Cooney TD, Engie K, Holzer DM (2009) Linking landscape-level change to habitat quality: an evaluation of restoration actions on the freshwater habitat of spring-run Chinook salmon. Freshw Biol 54:1560-1575

Keefer ML, Caudill CC (2014) Homing and straying by anadromous salmonids: a review of mechanisms and rates. Rev Fish Biol Fish 24:333-368

Lapointe M, Eaton B, Driscoll S, Latulippe C (2000) Modelling the probability of salmonid egg pocket scour due to floods. Can J Fish Aquat Sci 57:1120-1130

* Leppi JC, Rinella DJ, Wilson RR, Loya WM (2014) Linking climate change projections for an Alaskan watershed to future coho salmon production. Glob Change Biol 20: $1808-1820$

Mantua NJ, Hare SR, Zhang Y, Wallace JM, Francis RC (1997) A Pacific interdecadal climate oscillation with impacts on salmon production. Bull Am Meteorol Soc 78: 1069-1079

*Mantua N, Tohver I, Hamlet A (2010) Climate change impacts on streamflow extremes and summertime stream temperature and their possible consequences for freshwater salmon habitat in Washington State. Clim Change 102:187-223

Marcogliese DJ (2001) Implications of climate change for parasitism of animals in the aquatic environment. Can J Zool 79:1331-1352

McClure MM, Utter FM, Baldwin C, Carmichael RW and others (2008) Evolutionary effects of alternative artificial propagation programs: implications for viability of endangered anadromous salmonids. Evol Appl 1:356-375

* McClure MM, Alexander M, Borggaard D, Boughton D and others (2013) Incorporating climate science in applications of the U.S. Endangered Species Act for aquatic species. Conserv Biol 27:1222-1233

McCormick JH, Hokanson KEF, Jones BR (1972) Effects of temperature on growth and survival of young brook trout Salvelinus fontinalis. J Fish Res Board Can 29:1107-1112

Medina AL, Rinne JN, Roni P (2005) Riparian restoration through grazing management: considerations for monitoring project effectiveness. In: Roni P (ed) Monitoring stream and watershed restoration. American Fisheries Society, Bethesda, MD, p 97-126

Mote PW, Salathé EP (2010) Future climate in the Pacific Northwest. Clim Change 102:29-50

Moussalli E, Hilborn R (1986) Optimal stock size and harvest rate in multistage life history models. Can J Fish Aquat Sci 43:135-141

*Muhlfeld CC, Kovach RP, Jones LA, Al-Chokhachy R and others (2014) Invasive hybridization in a threatened species is accelerated by climate change. Nat Clim Change $4: 620-624$

National Marine Fisheries Service (NMFS) (1999) Endangered and threatened species: threatened status for three Chinook salmon Evolutionarily Significant Units (ESUs) in Washington and Oregon, and endangered status for one Chinook salmon ESU in Washington. National Marine Fisheries Service (NMFS), National Oceanic and Atmospheric Administration (NOAA), Department of Commerce, Washington, DC

Neville HM, Isaak DJ, Dunham JB, Thurow RF, Rieman BE (2006) Fine-scale natal homing and localized movement as shaped by sex and spawning habitat in Chinook salmon: insights from spatial autocorrelation analysis of individual genotypes. Mol Ecol 15:4589-4602

Overland JE, Wang M (2007) Future climate of the north Pacific Ocean. Eos Trans AGU 88:178-182

*Palmer MA, Reidy Liermann CA, Nilsson C, Flörke M, Alcamo J, Lake PS, Bond N (2008) Climate change and the world's river basins: anticipating management options. Front Ecol Environ 6:81-89

* Petersen JH, Kitchell JF (2001) Climate regimes and water temperature changes in the Columbia River: bioenergetic implications for predators of juvenile salmon. Can J Fish Aquat Sci 58:1831-1841 
Pollock MM, Beechie TJ, Liermann M, Bigley RE (2009) Stream temperature relationships to forest harvest in western Washington. J Am Water Resour Assoc 45: 141-156

Quinn TP, Dittman AH (1990) Pacific salmon migrations and homing: mechanisms and adaptive significance. Trends Ecol Evol 5:174-177

Quinn TP, Stewart IJ, Boatright CP (2006) Experimental evidence of homing to site of incubation by mature sockeye salmon, Oncorhynchus nerka. Anim Behav 72:941-949

Radchuk V, Turlure C, Schtickzelle N (2013) Each life stage matters: the importance of assessing the response to climate change over the complete life cycle in butterflies. J Anim Ecol 82:275-285

Richter A, Kolmes SA (2005) Maximum temperature limits for Chinook, coho, and chum salmon, and steelhead trout in the Pacific Northwest. Rev Fish Sci 13:23-49

Ruesch AS, Torgersen CE, Lawler JJ, Olden JD, Peterson EE, Volk CJ, Lawrence DJ (2012) Projected climateinduced habitat loss for salmonids in the John Day River network, Oregon, USA. Conserv Biol 26:873-882

Runge CA, Martin TG, Possingham HP, Willis SG, Fuller RA (2014) Conserving mobile species. Front Ecol Environ 12: 395-402

Scheuerell MD, Williams JG (2005) Forecasting climateinduced changes in the survival of Snake River spring/ summer Chinook salmon (Oncorhynchus tshawytscha). Fish Oceanogr 14:448-457

Scheuerell MD, Hilborn R, Ruckelshaus MH, Bartz KK, Lagueux KM, Haas AD, Rawson K (2006) The Shiraz model: a tool for incorporating anthropogenic effects and fish-habitat relationships in conservation planning. Can J Fish Aquat Sci 63:1596-1607

Seaber PR, Kapinos FP, Knapp GL (1987) Hydrologic unit maps. United States Geological Survey, Reston, VA

Seavy NE, Gardali T, Golet GH, Griggs FT and others (2009)

Editorial responsibility: Nils Chr. Stenseth, Oslo, Norway
Why climate change makes riparian restoration more important than ever: recommendations for practice and research. Ecol Res 27:330-338

* Seney EE, Rowland MJ, Lowery RA, Griffis RB, McClure MM (2013) Climate change, marine environments, and the U.S. Endangered Species Act. Conserv Biol 27: $1138-1146$

Snyder MA, Sloan LC, Diffenbaugh NS, Bell JL (2003) Future climate change and upwelling in the California Current. Geophys Res Lett 30:1823

Torgersen CE, Price DM, Li HW, McIntosh BA (1999) Multiscale thermal refugia and stream habitat associations of Chinook salmon in northeastern Oregon. Ecol Appl 9: 301-319

Velsen FPJ (1987) Temperature and incubation in Pacific salmon and rainbow trout: compilation of data on median hatching time, mortality, and embryonic staging. Can Data Rep Fish Aquat Sci 626:1-58

Wade AA, Beechie TJ, Fleishman E, Mantua NJ and others (2013) Steelhead vulnerability to climate change in the Pacific Northwest. J Appl Ecol 50:1093-1104

Waples RS, Beechie TJ, Pess GR (2009) Evolutionary history, habitat disturbance regimes, and anthropogenic changes: What do these mean for resilience of Pacific salmon populations? Ecol Soc 14:3

Warner MD, Mass CF, Salathé EP (2015) Changes in winter atmospheric rivers along the North American west coast in CMIP5 climate models. J Hydrometeorol 16:118-128

* Yvon-Durocher G, Montoya JM, Trimmer M, Woodward G (2011) Warming alters the size spectrum and shifts the distribution of biomass in freshwater ecosystems. Glob Change Biol 17:1681-1694

Zabel RW, Scheuerell MD, McClure MM, Williams JG (2006) The interplay between climate variability and density dependence in the population viability of Chinook salmon. Conserv Biol 20:190-200

Submitted: June 1, 2015; Accepted: September 30, 2016 Proofs received from author(s): December 4, 2016 